\title{
A Review of Current Knowledge on Staphylococcus agnetis in Poultry
}

\author{
Gustaw M. Szafraniec *, Piotr Szeleszczuk and Beata Dolka *(1) \\ Department of Pathology and Veterinary Diagnostics, Institute of Veterinary Medicine, Warsaw University of \\ Life Sciences-SGGW, Nowoursynowska 159c St., 02-776 Warsaw, Poland; piotr_szeleszczuk@sggw.edu.pl \\ * Correspondence: gmszafraniec@gmail.com (G.M.S.); beata_dolka@sggw.edu.pl (B.D.)
}

Received: 26 June 2020; Accepted: 11 August 2020; Published: 14 August 2020

check for updates

Simple Summary: This literature review provides a synthesis and evaluation of the current knowledge on Staphylococcus agnetis (S. agnetis) and its implications in poultry pathology. Recent studies revealed that $S$. agnetis can cause bacterial chondronecrosis with osteomyelitis (BCO), endocarditis, and septicemia in broiler chickens. Lameness constitutes one of the major health and welfare problems causing huge economic losses in the poultry industry. To date, a range of infectious and non-infectious factors have been associated with lameness in poultry. Among bacteria of the genus Staphylococcus, Staphylococcus aureus is the main species associated with locomotor problems. This contrasts with S. agnetis, which until recently had not been considered as a poultry pathogen. Previously only reported in cattle, S. agnetis has expanded its host range to chickens, and due to its unique characteristics has become recognized as a new emerging pathogen. The genotypic and phenotypic similarities between S. agnetis and other two staphylococci (S. hyicus and S. chromogenes) make this pathogen capable of escaping recognition due to misidentification. Although a significant amount of research on S. agnetis has been conducted, many facts about this novel species are still unknown and further studies are required to understand its full significance in poultry pathology.

Abstract: This review aims to summarize recent discoveries and advancements regarding the characteristics of Staphylococcus agnetis (S. agnetis) and its role in poultry pathology. S. agnetis is an emerging pathogen that was primarily associated with mastitis in dairy cattle. After a presumed host jump from cattle to poultry, it was identified as a pathological agent in broiler chickens (Gallus gallus domesticus), causing lameness induced by bacterial chondronecrosis with osteomyelitis (BCO), septicemia, and valvular endocarditis. Economic and welfare losses caused by lameness are global problems in the poultry industry, and S. agnetis has been shown to have a potential to induce high incidences of lameness in broiler chickens. S. agnetis exhibits a distinct repertoire of virulence factors found in many different staphylococci. It is closely related to S. hyicus and S. chromogenes, hence infections caused by $S$. agnetis may be misdiagnosed or even undiagnosed. As there are very few reports on S. agnetis in poultry, many facts about its pathogenesis, epidemiology, routes of transmission, and the potential impacts on the poultry industry remain unknown.

Keywords: Staphylococcus agnetis; poultry; broiler chicken; chondronecrosis; osteomyelitis; bovine mastitis

\section{Introduction}

The genus Staphylococcus belongs to the phylum Firmicutes, class Bacilli, order Bacillales, family Staphylococcaceae. As new research emerges, systematic relations within the genus Staphylococcus are constantly changing. Almost 60 Staphylococcus species have been identified, three of which were described as recently as last year (2019). New findings may cause some strains to be reclassified, as has 
been done for isolates previously identified as Staphylococcus intermedius. Most of these isolates are now recognized as Staphylococcus pseudintermedius. Together with Staphylococcus delphini, these three hard-to-differentiate species form a distinct $S$. intermedius group (SIG) [1].

Bacteria of the genus Staphylococcus are characterized by spherical, Gram-positive cells that occur singly, in pairs, or in small clusters. With a few exceptions, they are facultative anaerobes that are usually catalase-positive and oxidase-negative [2]. Staphylococci are ubiquitous in the poultry farm environment and belong to the normal bacterial microbiota of the skin and mucous membranes of healthy birds, including poultry and pigeons [1-3]. However, some species can cause opportunistic infections (Table 1). Such infections are common in poultry and are mainly caused by Staphylococcus aureus, the species most frequently isolated from birds diagnosed with staphylococcosis and the most pathogenic Staphylococcus species [3-6]. Locations from which S. aureus has been most commonly isolated include the proximal femur, proximal tibiotarsus, tendon sheaths, hock joints, pododermatitis lesions, heart, and liver [3,6-14]. Diseases promoted by staphylococci are often chronic in nature. Clinical symptoms and lesions vary with the site of entry of the pathogen and are primarily associated with bones, joints, and tendon sheaths; and less often with skin, heart, vertebrae, and other locations. Septicemia can develop following skin or mucous membrane infections. The most common findings in sick birds are lameness and fever, which can be followed by depression and death $[3,6,7,15]$.

Staphylococcal infections are a global welfare and economic problem in poultry production. Economic losses are largely associated with lameness and its consequences, such as decrease in production parameters, increase in mortality, culling, and condemnation of carcasses at slaughterhouses. Staphylococcosis also contributes to reduced poultry welfare due to pain, stress, and decreased locomotive abilities [3,6,16-18].

Other noteworthy infectious agents associated with lameness in poultry include Enterococcus spp., Streptococcus spp., avian reovirus, Marek's disease virus (MDV), chicken infectious anemia virus (CIAV), and infectious bursal disease virus (IBDV) [6,19-23]. Other than infections, there are also non-infectious factors that can cause abnormal skeletal development leading to lameness. Nutritional or metabolic imbalances, such as vitamin D deficiency, as well as phosphorus and calcium imbalances, have been associated with rickets, osteoporosis, and tibial dyschondroplasia [24-28]. Management practices and housing conditions, such as the bedding type, litter condition, lighting program, and stocking density, have been linked to higher incidences of leg disorders [29-34]. Previous research has highlighted associations between genetics, breed line, gender, growth rate, age, and leg problems in broiler chickens $[16,31,35,36]$. For many decades, genetic selection of broiler chickens was focused on improving the feed conversion rate and promoting rapid growth of chickens. Nowadays, broiler chickens can grow to $1.5 \mathrm{~kg}$ of body weight before they reach 30 days of age, while in the 1950s, reaching such weight would take 120 days [16,37]. Fast-growing chickens have higher nutritional requirements, which when not met, can lead to skeletal deformities. Additionally, their bones have less time to mature to be able to carry the excessive body weight [37]. The leg bone tissue of fast-growing chickens is more porous and less mineralized compared with that of slower-growing chickens, which makes fast-growing chickens more prone to bone deformities and leg trauma leading to lameness and pain [37-39]. In recent years, broiler selection programs have started to put more emphasis on improving health and welfare issues, such as skeletal integrity, cardiovascular fitness, and immunity [16].

Table 1. List of Staphylococcus species associated with infections in poultry.

\begin{tabular}{cccc}
\hline Staphylococcus Species & $\begin{array}{c}\text { Poultry Species and } \\
\text { Production Type }\end{array}$ & Diseases & Reference \\
\hline S. agnetis & $\begin{array}{c}\text { Broiler chicken, } \\
\text { broiler breeder }\end{array}$ & $\begin{array}{c}\text { Bacterial chondronecrosis with osteomyelitis, } \\
\text { endocarditis, septicemia }\end{array}$ & {$[40,41]$} \\
\hline
\end{tabular}


Table 1. Cont

\begin{tabular}{|c|c|c|c|}
\hline Staphylococcus Species & $\begin{array}{l}\text { Poultry Species and } \\
\text { Production Type }\end{array}$ & Diseases & Reference \\
\hline S. aureus & $\begin{array}{l}\text { All poultry species } \\
\text { and production types }\end{array}$ & $\begin{array}{c}\text { Arthritis, synovitis, } \\
\text { chondronecrosis, } \\
\text { osteomyelitis, } \\
\text { gangrenous dermatitis, } \\
\text { bumblefoot, } \\
\text { green liver-osteomyelitis syndrome, } \\
\text { omphalitis, } \\
\text { septicemia }\end{array}$ & {$[3,6-13]$} \\
\hline S. auricularis & Broiler chicken & Systemic infection & [42] \\
\hline S. capitis & $\begin{array}{l}\text { Broiler chicken, } \\
\text { laying hen, } \\
\text { broiler breeder }\end{array}$ & Systemic infection & {$[14,42]$} \\
\hline S. carnosus & Broiler turkey & Systemic infection & {$[14,42]$} \\
\hline S. chromogenes & $\begin{array}{l}\text { Broiler chicken, } \\
\text { broiler turkey, } \\
\text { laying hen, } \\
\text { broiler breeder, } \\
\text { waterfowl }\end{array}$ & Systemic infection & [14] \\
\hline S. cohnii subsp. urealyticus & $\begin{array}{l}\text { Broiler chicken, } \\
\text { broiler turkey, } \\
\text { laying hen, } \\
\text { broiler breeder, } \\
\text { waterfowl }\end{array}$ & $\begin{array}{l}\text { Hock joint arthritis, } \\
\text { systemic infections, } \\
\text { scabby hip syndrome }\end{array}$ & {$[14,42-44]$} \\
\hline S. epidermidis & $\begin{array}{l}\text { Broiler chicken, } \\
\text { laying hen, } \\
\text { waterfowl }\end{array}$ & $\begin{array}{c}\text { Chondronecrosis with osteomyelitis (BCO), } \\
\text { scabby hip syndrome, } \\
\text { systemic infection }\end{array}$ & {$[14,42,44]$} \\
\hline S. gallinarum & Broiler chicken & Systemic infection & [42] \\
\hline S. hominis & Broiler chicken & $\begin{array}{l}\text { Chondronecrosis with osteomyelitis (BCO), } \\
\text { systemic infections }\end{array}$ & {$[14,40,42]$} \\
\hline S. hyicus & $\begin{array}{l}\text { Broiler chicken, } \\
\text { laying hen, } \\
\text { broiler breeder, } \\
\text { turkey }\end{array}$ & $\begin{array}{c}\text { Systemic infections, } \\
\text { fibrinopurulent blepharitis and conjunctivitis, } \\
\text { mixed infections with fowl pox, } \\
\text { stifle joint osteomyelitis, } \\
\text { acantholytic folliculitis and epidermitis, } \\
\text { pododermatitis }\end{array}$ & {$[11,14,45-48]$} \\
\hline S. intermedius & Broiler chicken & $\begin{array}{l}\text { Systemic infections, } \\
\text { scabby hip syndrome }\end{array}$ & {$[42,44]$} \\
\hline S. lentus & $\begin{array}{l}\text { Broiler chicken, } \\
\text { broiler turkey, } \\
\text { broiler breeder, } \\
\text { laying hen, } \\
\text { waterfowl }\end{array}$ & $\begin{array}{l}\text { Systemic infections, } \\
\text { scabby hip syndrome }\end{array}$ & {$[14,42,44]$} \\
\hline S. lugdunensis & Broiler turkey & Systemic infections & [14] \\
\hline S. saprophyticus & $\begin{array}{l}\text { Broiler chicken, } \\
\text { broiler turkey, } \\
\text { laying hen }\end{array}$ & $\begin{array}{l}\text { Chondronecrosis with osteomyelitis }(\mathrm{BCO}), \\
\text { systemic infections }\end{array}$ & {$[14,40]$} \\
\hline S. schleiferi & Broiler chicken & Systemic infections & [14] \\
\hline S. sciuri & $\begin{array}{l}\text { Broiler chicken, } \\
\text { broiler turkey, } \\
\text { waterfowl }\end{array}$ & $\begin{array}{l}\text { Scabby hip syndrome, } \\
\text { systemic infection }\end{array}$ & {$[14,44]$} \\
\hline S. simulans & $\begin{array}{l}\text { Broiler chicken, } \\
\text { broiler turkey, } \\
\text { waterfowl }\end{array}$ & $\begin{array}{l}\text { endocarditis, } \\
\text { systemic infection, } \\
\text { scabby hip syndrome, }\end{array}$ & {$[14,42,44]$} \\
\hline S. warneri & $\begin{array}{l}\text { Broiler chicken, } \\
\text { broiler turkey, } \\
\text { laying hen }\end{array}$ & $\begin{array}{l}\text { Scabby hip syndrome, } \\
\text { systemic infection }\end{array}$ & {$[14,44]$} \\
\hline S. xylosus & $\begin{array}{l}\text { Broiler chicken, } \\
\text { broiler turkey, } \\
\text { broiler breeder, } \\
\text { waterfowl }\end{array}$ & $\begin{array}{l}\text { Chondronecrosis with osteomyelitis (BCO), } \\
\text { systemic infections }\end{array}$ & {$[14,40,42]$} \\
\hline
\end{tabular}




\section{Discovery and Identification of Staphylococcus agnetis}

The first isolation of $S$. agnetis was performed from milk samples of subclinical and mild clinical intramammary infections in dairy cattle in southern Finland [49]. It was noticed that most isolates identified by the API ${ }^{\circledR}$ Staph ID 32 test (bioMérieux, France) as S. hyicus did not cluster with any strain of known Staphylococcus species using amplified fragment length polymorphism (AFLP), which led to identification and description of this novel species. It was named in honor of Agnes Sjöberg (Finland, 1888-1964), who was the first female veterinary surgeon in Europe and the first woman in Europe with a doctoral degree in veterinary medicine (1918) [49]. Since then, S. agnetis has been isolated from cattle worldwide [50-58]. Later, it was discovered that $S$. agnetis is a causative agent of disease in broiler chickens and broiler breeders $[40,41]$.

S. agnetis is a Gram-positive, coagulase-variable, facultatively anaerobic bacterium. It belongs to non-motile, non-spore-forming cocci, which occur singly, in pairs, or in small clusters. On $5 \%$ bovine blood agar after $18-24 \mathrm{~h}$ aerobic incubation at $37^{\circ} \mathrm{C}$, the bacterium forms smooth, circular to irregular, slightly convex, opaque, light grey, and non-hemolytic colonies growing up to $2-3 \mathrm{~mm}$ in diameter [41,49] (Figure 1).

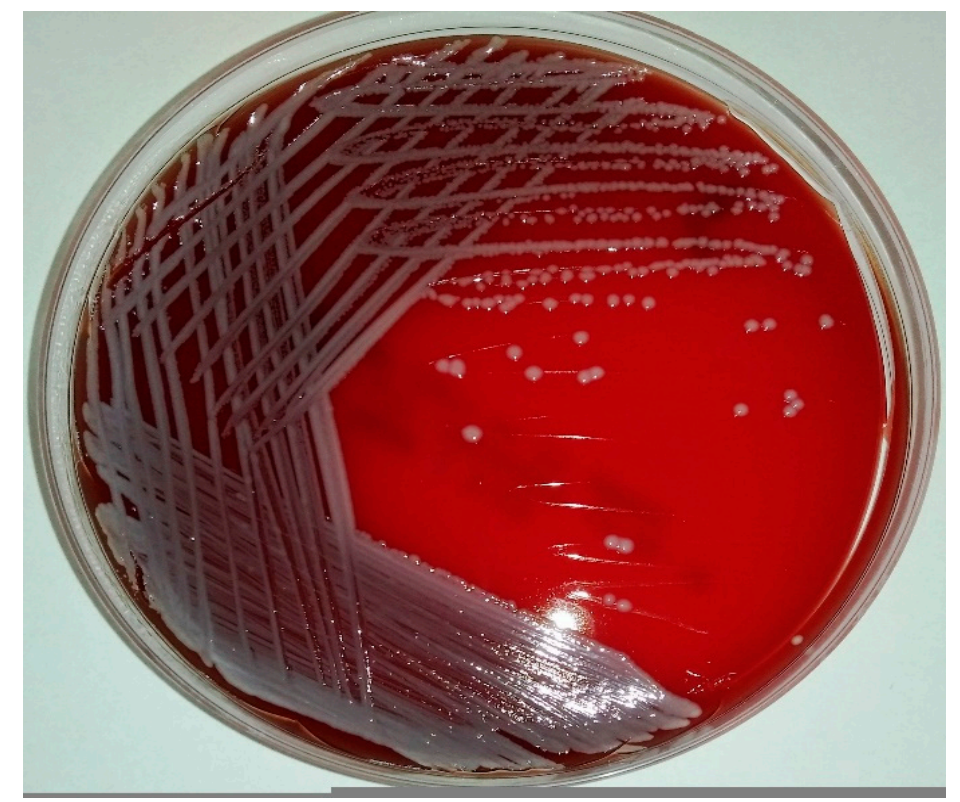

Figure 1. Colonies of S. agnetis (GenBank: MT231940) on Columbia agar with 5\% sheep blood.

Material for bacteriological tests should be collected aseptically from birds and plated on agar medium. Locations from which $S$. agnetis cultures have been successfully obtained include the proximal heads of the tibia and femur (either macroscopically normal or with BCO lesions), blood, liver, spleen, endocardium, and cloaca $[40,41]$. Basic media for staphylococcal samples are $5 \%$ blood agar (bovine or ovine blood), Müller-Hinton, or Trypticase Soy agar supplemented with blood [3,41,49,56]. In some cases, CHROMagar Orientation (DRG International, Union County, NJ, USA) has been used as a medium to initially differentiate cultured colonies [40,59].

Identification of $S$. agnetis and its differentiation from other staphylococci can be problematic. The morphologies of S. agnetis and S. hyicus colonies on blood agar are similar, which can lead to misidentification of these two species [41]. S. aureus colonies have yellowish pigmentation and are $\beta$-hemolytic or not hemolytic ( $\gamma$-hemolytic) [3,41,49].

S. agnetis falls into the group of coagulase-variable staphylococci, with studies reporting isolates that could be either predominantly coagulase-negative [49] or coagulase-positive [54]. Some strains exhibited a delayed coagulase reaction in a tube test, with $12-25 \%$ of strains being found to be 
coagulase-negative after $4 \mathrm{~h}$ but coagulase-positive after $24 \mathrm{~h}$. Clumping factor has been found to be negative [49,54], while the DNase test has been found to be positive [49].

Generally, biochemical tests (Table 2) can be used to differentiate between staphylococci $[3,60]$. However, they are a poor choice for $S$. agnetis identification. In addition, commercial biochemical identification systems (e.g., $\mathrm{API}{ }^{\circledR}$ ) cannot be used for identification of S. agnetis, as the species is not included in the comparison databases [61]. According to Taponen et al. [49], S. agnetis is very closely related to $S$. hyicus and $S$. chromogenes with regard to biochemical features. The authors demonstrated that within S. agnetis isolates, all but seven reactions gave identical results. The variable reactions were observed for glycogen utilization, $\beta$-glucuronidase, and acid production from D-galactose, amygdalin, melibiose, trehalose, and gentiobiose. However, not one of these reactions can be relied upon to distinguish S. agnetis from S. hyicus and S. chromogenes, as there are no instances of positive versus negative results between these species. Furthermore, tests for most of the differentiating reactions are not included in standard commercially available biochemical kits, making proper species identification even less likely. One study demonstrated that most staphylococci isolated from bovine milk, previously classified as coagulase-positive S. hyicus using phenotypic identification methods, were in fact not S. hyicus [54].

Matrix-assisted laser desorption/ionization-time of flight mass spectrometry (MALDI-TOF MS) has been used to confirm $S$. agnetis in poultry isolates after the type strain CCUG 59,809 of S. agnetis was added to the MALDI-TOF MS database as a reference [41]. However, MALDI-TOF MS and some genetic identification methods, such as $16 \mathrm{~S}$ rDNA or dnaJ (heat shock protein 40, Hsp40) gene sequencing, were not sufficiently accurate in differentiating S. agnetis from other Staphylococcus species in some studies [54,61]. Gene sequencing of the $\beta$ subunit of RNA polymerase (rpoB) and the elongation factor Tu $(t u f)$ can be used to differentiate S. agnetis and S. hyicus when using sufficiently high cut-off values [54,56]. Real-Time PCR based on the cytochrome d ubiquinol oxidase subunit II (cydB) gene may provide a new approach to complement MALDI-TOF MS and other methods for the rapid and accurate identification of $S$. agnetis and coagulase-negative staphylococci. All of the isolates that were classified as S. hyicus by MALDI-TOF MS were identified as S. agnetis by using cydB real-time PCR [62].

Taponen et al. [49] constructed phylogenetic trees based on the $16 \mathrm{~S} \mathrm{rDNA}$, rpoB, and tuf genes of 13 cattle S. agnetis isolates, as well as type strains of the genus Staphylococcus. The S. agnetis strains clustered closely together, indicating they belonged to a single species. They were distinct from S. hyicus ATCC 11,249 and S. chromogenes ATCC 43764, their closest relatives. An amplified fragment length polymorphism (AFLP) analysis using the restriction enzymes HindIII-MseI and DNA-DNA hybridization (at a threshold value of 70\%) proved to be useful tools for the differentiation of S. agnetis from S. hyicus and S. chromogenes [49]. S. agnetis can be identified to the species level by comparison of AFLP fingerprints with a large staphylococcal library or by a combination of $r p o B$ gene sequencing and AFLP clustering [63].

A phylogenetic tree based on the 16S rDNA gene sequences of chicken S. agnetis (strain 908) and other staphylococci shows that $S$. agnetis clusters closely with S. hyicus and S. chromogenes [40]. S. hyicus is an etiological factor for swine exudative epidermitis and is frequently isolated from bovine mastitis [54,64]. In poultry, it is a common skin commensal bacterium known to cause opportunistic infections (Table 1). S. chromogenes is a common finding in cases of dairy cow mastitis [57,65]. In poultry, it is considered as a normal inhabitant of the skin and mucous membranes $[64,66]$, although it has been reported to cause opportunistic infections [14] (Table 1). S. hyicus and S. chromogenes were not considered as separate species before 1986 [66], and similarly S. agnetis has only recently been acknowledged as a separate species from $S$. hyicus [49]. It should be noted that most cases of opportunistic infections caused by S. hyicus in poultry (Table 1) had been reported before S. agnetis was recognized as a distinct species. There is a possibility that $S$. agnetis diverged from $S$. hyicus a long time ago, and some of the infections, which back then were diagnosed as $S$. hyicus infections, might have been caused by S. agnetis. Adkins et al. [54] theorized that misidentification of species of coagulase-positive non-aureus Staphylococcus species may be a widespread phenomenon. In their study, genetic methods based 
on selected housekeeping genes were proven to be the most accurate and were used to decisively confirm whether the isolated species was S. hyicus or S. agnetis. Re-testing the cattle isolates, designated by phenotypic test (API ${ }^{\circledR}$ Staph; bioMérieux, Lyon, France) as $S$. hyicus, using tuf gene sequencing led to their identification as S. agnetis $(69.4 \%, 43 / 62)$, S. chromogenes $(12.9 \%, 8 / 62)$, and S. aureus $(8 \%$, $5 / 62)$, with only $1.6 \%$ (1/62) confirmed as $S$. hyicus. The remaining $8 \%(5 / 62)$ were of various other Staphylococcus species. To better differentiate between S. hyicus, S. agnetis, and S. aureus, a method using the multiplex PCR assay combined with pulsed-field gel electrophoresis (PFGE) was proposed. In multiplex PCR, a partial segment of the aroD gene (3-dehydroquinate dehydratase) was amplified to identify S. hyicus and S. agnetis, while the nuc gene (thermonuclease) was amplified to identify S. aureus $[54,56]$.

Table 2. Comparison of selected tests or biochemical characteristics of S. agnetis with other Staphylococcus species.

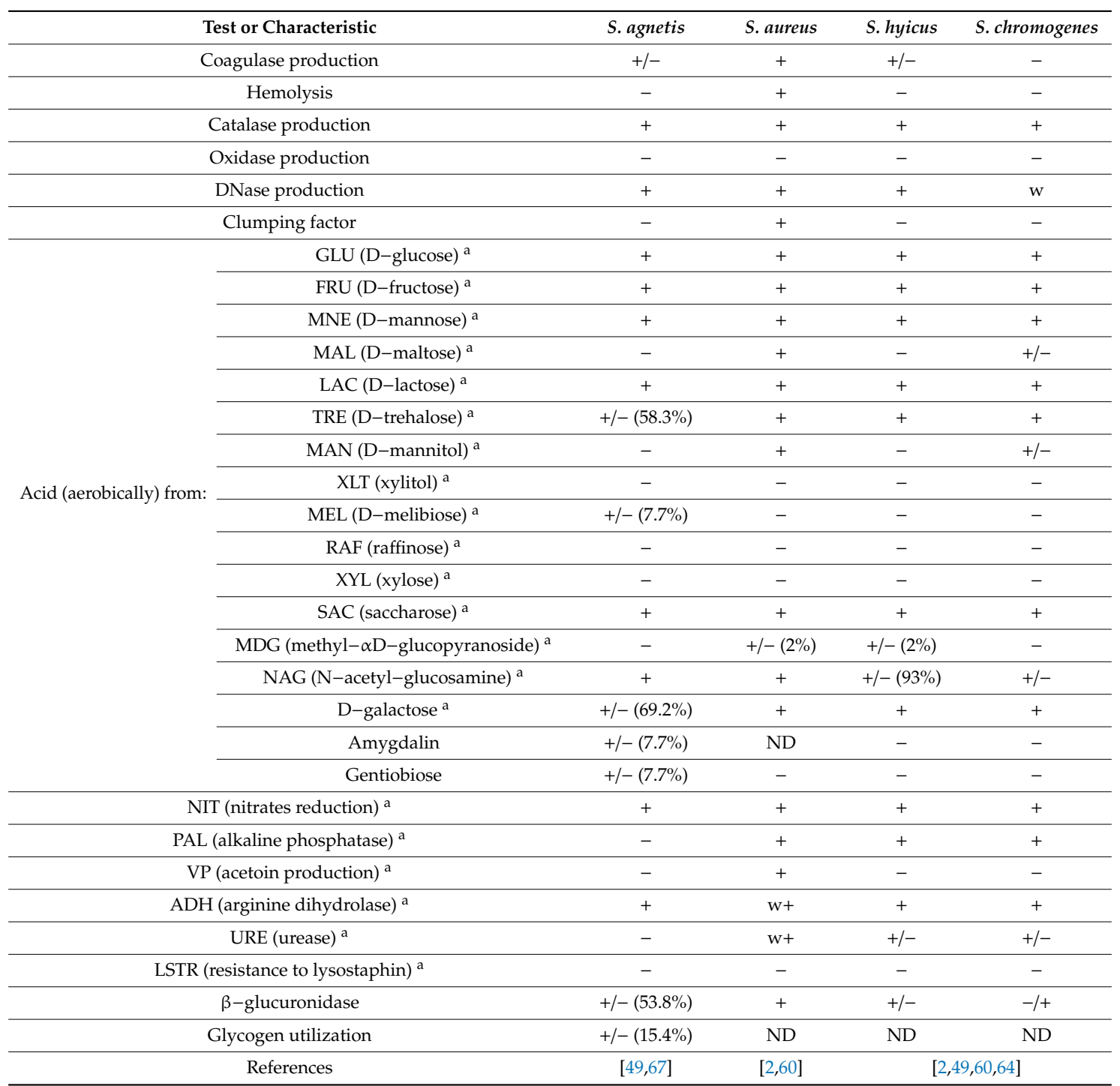

Note: + , positive; - , negative; $+/-$, variable; $(n \%)$, percentage of positive reactions; $\mathrm{w}$, weak reaction; $\mathrm{w}+$, positive to weak reaction; ND, test not determined; ${ }^{a}$, test included in commercial API ${ }^{\circledR}$ Staph (bioMérieux, France).

\section{Role of S. agnetis in Poultry Pathology}

S. agnetis has been primarily associated with bovine mastitis [49,51-55,57]. Since 2015 it has been identified as an etiological factor responsible for bacterial chondronecrosis with osteomyelitis (BCO) [40,59], endocarditis and septicemia in broiler chickens (Gallus gallus domesticus) [41] (Table 3). 


\subsection{Bacterial Chondronecrosis with Osteomyelitis (BCO)}

Bacterial chondronecrosis with osteomyelitis (BCO) is a predominant cause of lameness in broiler chickens. Lameness is a significant cause of economic losses in the poultry industry, as well as a major concern for the welfare of the birds. In the 1970s, when BCO was first reported in Australia as a common cause of leg weakness in chickens, the incidence of lameness due to BCO in commercial broiler chicken flocks reached $50 \%$, with up to 5\% mortality of birds aged 4-8 weeks [68]. According to a later study, BCO was the most common cause of lameness and was found in $17.3 \%$ of lame chickens (33/191). Overall, BCO was diagnosed by histopathology in 13.7\% (57/416) of the total dead and culled birds [6]. In another study, BCO in the proximal end of the femur and in the proximal end of the tibiotarsus was found in $20.4 \%$ of birds [7]. Overall, approximately $30 \%$ of commercially reared broiler chickens in the European Union have been reported to present leg abnormalities resulting in the decrease of locomotor functions [16,31,69]. According to Wijesurendra et al. [70], BCO occurs throughout the life of a broiler chicken flock at a very high rate, and the prevalence of histologically confirmed $\mathrm{BCO}$ is $28 \%$ (95\% confidence interval (CI): $23-34 \%$ ) of mortalities and culls. In addition to the welfare concerns, the annual economic losses due to leg problems for the poultry industry in the United States have been estimated at \$80-120 million in broiler chickens and \$40 million in turkeys [71]. In the UK, the overall losses associated with BCO were approximately $0.75 \%$ of male chickens of all bird placements, which cost the UK broiler industry $£ 3$ million annually. Another author found that BCO constitutes approximately $0.5-0.7 \%$ of the losses (through mortality and culling) from the total annual UK broiler production, which represents 3.75 million birds and costs $£ 4.7$ million [19]. Based on the above calculations, it has been estimated that 12.5 billion broiler chickens have leg problems worldwide per year [72].

$\mathrm{BCO}$ forms when the rapidly increasing weight of a growing chicken exerts excessive mechanical stress on epiphyseal and physeal cartilages, most notably of the proximal femur and tibia, creating osteochondrotic microfractures that can be colonized by hematogenously disseminated bacteria. These bacteria can form osseous sequestration, which may develop into necrotic lesions [23]. The first reported case of $S$. agnetis in poultry came from broilers experimentally reared on an elevated wire flooring [40], a model designed specifically to induce BCO and enhance its prevalence [23,73]. Although many different opportunistic bacteria (e.g., S. aureus, Escherichia coli, Enterococcus cecorum) were previously isolated from BCO lesions [23,40,73], in one study the majority $(87.1 \%, 81 / 93)$ of isolates from BCO and blood of lame birds belonged to a single species-S. agnetis [40]. It was demonstrated that $S$. agnetis could be isolated from different sites of the same bird, and even from macroscopically normal bones. In those cases, bacteria were not cultured from blood samples, which indicated that bacteria in the bone did not originate from a generalized (systemic) infection [40]. One isolate out of 81 was designated as S. agnetis strain 908 and chosen by Al-Rubaye et al. [40] for detailed analyses and further studies [59].

It was confirmed that administration of live S. agnetis (strain 908) into drinking water induces high incidences of lameness $(>50 \%)$ in broilers when combined with the wire flooring model [40,59]. Even though inoculation with $S$. agnetis happened early in the chicks' lives, the first lame birds became identifiable only from day 35, which means that BCO lameness can be induced by exposing birds to S. agnetis at an early age [59]. This implies that S. agnetis 908 is able to persist in birds, possibly in the intestinal tract $[23,59]$, until later in life when it enters the bloodstream and colonizes growth plates of the rapidly growing leg bones. The mechanism of survival of S. agnetis in the chicken intestines is unknown, however since S. agnetis shares some virulence determinants with S. aureus [40], it could be similar to mechanisms proposed and demonstrated in vitro for human S. aureus strains. Some authors showed that $S$. aureus can adhere to the mucus of the intestinal tract [74], while other demonstrated that $S$. aureus can be internalized by enterocytes and survive in this way for prolonged periods of time [75,76]. A model for BCO pathogenesis proposed by Wideman [23] is based on the ability of opportunistic pathogenic bacteria to translocate across the intestinal tract into the blood. Probiotics have the potential to combat enteral bacterial infections by means of competitive exclusion and other 
modes of action [77-79]. It has been demonstrated that the use of some probiotics in chickens raised on the wire flooring model can reduce the prevalence of lameness [73,80]. However, the same probiotics when administered in feed or water were unable to reduce the incidence of lameness when birds were challenged with the minimal effective dose of S. agnetis (strain 908). This shows that S. agnetis was able to overcome the protective properties of the probiotics used [59].

When birds were challenged simultaneously with S. agnetis (strain 908) and the human strain of S. aureus ATCC 27661, all cultures from BCO lesions yielded only S. agnetis [40]. This suggests either that $S$. agnetis is much more effective at colonizing growth plates and inducing BCO lameness than S. aureus ATCC 27661, or that this particular strain of $S$. aureus is unable to do so, which may be due to its lack of virulence determinants adapted to the chicken host $[59,81,82]$. Comparing chickens challenged with S. agnetis 908 and two other staphylococci isolated from BCO lesions (S. saprophyticus and $S$. epidermidis), authors showed that these two species induce lameness to a significantly lesser extent (cumulative \% lameness: S. saprophyticus $57.4 \%$, S. epidermidis $52.3 \%$ ) than S. agnetis (80.5\%) or no challenge (control group) $(71.7 \%)$. The unchallenged control group yielded nearly as many lame birds as the group challenged with $S$. agnetis 908, which could indicate that the experimental environment of the research facility became heavily loaded with S. agnetis [59]. In addition, S. agnetis could have been transmitted from challenged to unchallenged birds in the same pen. The fact that challenges with S. saprophyticus and S. epidermidis resulted in lower degrees of lameness than in the group challenged with S. agnetis 908 (and the unchallenged group) could point towards their lower virulence for poultry. Furthermore, it may be assumed that $S$. saprophyticus and S. epidermidis have a potential protective effect against the acquisition of S. agnetis 908 from the environment. There may be ecological interactions between S. agnetis and other Staphylococcus species that may be important factors for both colonization and BCO induction.

Table 3. A summary of current studies of Staphylococcus agnetis in poultry.

\begin{tabular}{|c|c|c|c|}
\hline Year & Country & Brief Conclusions & Reference \\
\hline 2015 & USA & $\begin{array}{l}\text { - S. agnetis can be isolated from the blood, femur, and tibia of lame chickens reared on } \\
\text { elevated wire flooring. } \\
\text { - S. agnetis is determined to be an etiological agent of lameness associated with } \\
\text { bacterial chondronecrosis with osteomyelitis (BCO). } \\
\text { - S. agnetis administered in the drinking water induces lameness. } \\
\text { - Whole genome analysis shows S. agnetis to possess virulence factors from many } \\
\text { different staphylococci. } \\
\text { - Closest relatives to S. agnetis are S. hyicus and S. chromogenes. }\end{array}$ & [40] \\
\hline 2017 & USA & $\begin{array}{l}\text { - Minimal effective dose and optimal time for S. agnetis administration in the } \\
\text { experimental challenge model are determined. } \\
\text { S. agnetis administered in the water to chickens at an early age can induce BCO } \\
\text { lameness later in life and overwhelms the protective properties of some probiotics. } \\
\text { - S. agnetis is transmittable between chickens. }\end{array}$ & [59] \\
\hline 2017 & Denmark & $\begin{array}{l}\text { - S. agnetis infection can cause broiler breeder mortality associated with endocarditis } \\
\text { and septicemia in broiler breeders. } \\
\text { - S. agnetis is also found in cloacal microbiota of a small number of newly hatched } \\
\text { chicks originating from afflicted farms. } \\
\text { - It is possible that S. agnetis can be transmitted from broiler breeders to their offspring. }\end{array}$ & [41] \\
\hline 2020 & USA & $\begin{array}{l}\text { - Whole genome comparisons between chicken and cattle } S \text {. agnetis isolates show that } \\
\text { S. agnetis most likely performed a single host jump from cattle to poultry. } \\
\text { No identified genes are currently associated with chicken host specialization, } \\
\text { meaning that it could have been facilitated by minute mutations in a few genes } \\
\text { associated with virulence factors. }\end{array}$ & [83] \\
\hline
\end{tabular}

Al-Rubaye et al. [59] and Shwani et al. [83] pointed out that it is likely that S. agnetis 908 represents a hypervirulent clone that evolved from less virulent $S$. agnetis strains circulating in broiler populations 
at the research facility. The low level of genetic diversity has been observed between S. agnetis isolates retrieved from BCO chickens. Due to many years of passages and selective pressure on the wire flooring at the research facility, S. agnetis strain 908 became highly capable of inducing BCO lameness [59,83]. It seemed to be specific for that research facility.

\subsection{Endocarditis and Septicemia}

Valvular endocarditis is one of possible outcomes of infection with Staphylococcus spp. and other bacteria. It occurs when septicemic bacterial infection progresses to a subacute or chronic stage [84]. Endocarditis caused by $S$. aureus is well documented in humans [85,86], and has been reported in poultry [87]. Staphylococcus simulans has also been associated with endocarditis in broilers [88]. Bacteria of genera other than Staphylococcus that have been associated with natural or experimental poultry infections resulting in bacterial endocarditis include Avibacterium endocarditidis, Enterococcus faecalis, E. faecium, E. hirae, E. durans, Streptococcus pluranimalium, S. gallolyticus, S. gallinaceus, S. zooepidemicus, Pasteurella multocida, Erysipelothrix rhusiopathiae, and Helcococcus ovis [87,89-93].

The prevalence of bacterial endocarditis in poultry is not well described in the literature, with case studies reporting sporadic incidences that are usually limited to one flock or farm. According to reports from the 1960s [94], mortality due to endocarditis in a flock was less than $0.5 \%$. Valvular endocarditis may be found in $15 \%$ of chickens older than 40 weeks of age, while in only $3 \%$ of chickens between 10 and 40 weeks of age. Out of $62 \%$ losses due to septicemia in broiler breeders, $34 \%$ of birds suffered from bacterial valvular endocarditis [87]. Increased mortality (17-20.1\%) has also been observed in broiler breeder flocks, in which $29 \%$ of birds developed valvular endocarditis [95]. According to Velkers et al. [96], bacterial endocarditis may be responsible for $36 \%$ of the total mortality during the production of commercial broiler chickens. In other studies, endocarditis caused by S. aureus was noted in 5\% of all affected birds [87], while that caused by S. simulans was noted in $40 \%$ of tested birds [88].

During longitudinal studies of broiler breeder mortality in four flocks in Denmark, Poulsen et al. [41] demonstrated S. agnetis to be an etiological agent for valvular endocarditis and septicemia in broiler breeders. S. agnetis was isolated in pure culture from $2.7 \%(n=16)$ of all examined broiler breeders that died due to an infection. In these sixteen cases, isolates were obtained from the endocardium, liver, or spleen. Endocarditis was the primary cause of death in six hens (37.5\%), four of which also showed signs of septicemia manifested as disseminated necrotic foci in the liver. In three cases (18.75\%), septicemia with enlarged liver or spleen and circulatory shock was indicated as the cause of death. In the remaining seven cases $(43.75 \%)$, hens died of other causes, but S. agnetis was isolated from the liver or spleen, and in one instance from the endocardium, despite the absence of endocarditis lesions (6.25\%). It was assumed that in these seven cases, S. agnetis infections were secondary. It was speculated that $S$. agnetis could have a predisposition to injured endothelial cells, as has been shown in cases of human S. aureus endocarditis [41,97].

\section{Genome Characteristics of S. agnetis}

The first S. agnetis genome was characterized in 2014 [51]. The authors presented a draft genome sequence for an isolate obtained from a lactating dairy cow with subclinical mastitis. The genome of the mastitic isolate was approximately $2.42 \mathrm{Mbp}$. Al-Rubaye et al. [40] reported the first genome analysis of $S$. agnetis originating from poultry (strain 908). The estimated size of the genome of chicken S. agnetis was $2.47 \mathrm{Mbp}$. Recently, Shwani et al. [83] assembled a genome of S. agnetis 1416 isolate obtained from a commercial broiler farm and identified additional plasmids in poultry isolates [83].

When all predicted protein sequences were compared to other Staphylococcus spp. genomes (S. hyicus, S. pseudintermedius, S saprophyticus, and five S. aureus from public databases), it was found that the majority of S. agnetis 908 predicted proteins had their closest homologs in S. hyicus (87.1\%) [40]. Homologs in other species were found for $5.1 \%$ of the predicted proteins, while $8.5 \%$ had no match in the database. The closest homologs other than those from S. hyicus were most numerous within Bacillus spp. and other Staphylococcus spp. When S. hyicus genome was excluded from comparison, the next closest 
homologs to S. agnetis 908 genes were found most frequently in canine S. pseudintermedius, followed by the human Staphylococcus member HGB0015 GN and human S. aureus. The assembled genome of S. agnetis 908 differs from the $S$. hyicus genome in at least five notable regions. These regions contain orthologs to genes from various Gram-positive and Gram-negative bacteria [40].

A comparison of the genomes of different poultry S. agnetis strains with that of S. agnetis 908 showed little to no diversity in the main chromosome. However, most of the differences occurred in the plasmid, making it hypervariable in S. agnetis isolates. [40]. After performing a BLASTN search on all three assembled plasmids of S. agnetis 908 against 26 S. agnetis genomes present in the NCBI database, Shwani et al. [83] concluded that none of these plasmids seems to harbor genes determining chicken host specialization.

Pulsed-field gel electrophoresis (PFGE) typing of the Danish isolates of S. agnetis from broiler breeders and newly hatched chickens showed that the isolates were divided into seven types based on the PFGE band patterns. In total, 29 isolates were tested. These were obtained from the liver $(n=10)$, spleen $(n=4)$, and heart $(n=2)$ of broiler breeders, as well as cloacal swabs of newly hatched chickens $(n=13)$. One PFGE type seemed to be predominant and included both isolates from septicemia in broiler breeders from three different farms, as well as isolates from newly hatched chicks derived from one of these farms. This could indicate that $S$. agnetis may be transmitted from breeders to their offspring [41].

\section{Virulence Factors of S. agnetis}

S. agnetis has a distinct repertoire of virulence factors with homologs to both pathogenic and non-pathogenic staphylococci. Virulence factors belonging to the classes of host immune evasion, host adherence, toxin biosynthesis, and secretion systems were identified. Among these, the most noteworthy were master regulatory virulence genes found in S. aureus [40].

Exotoxins produced by S. agnetis 908 consist of five superantigen-like proteins (also identified in the Danish isolates [41]), a $\beta$-hemolysin, and an exfoliative toxin A. When compared with some other Staphylococcus species (S. hyicus, S. aureus, S. pseudintermedius, S. chromogenes), they showed varied relatedness, sometimes contrary to what could be expected based on the 16S rDNA phylogenetic tree [40]. Exotoxins have been found to be crucial in the pathogenesis of staphylococcal infections, interacting with host cells and tissues in various ways [98-101].

Staphylococcal superantigen-like proteins (SSLs) are a group of virulence factors known for their ability to manipulate the host's immune system [98]. One of the SSLs, SSL7, is able to bind immunoglobulin A (IgA), an important element of local mucosal immunity, contributing to the survival of staphylococci on the surface of mucous membranes, i.e., inside the gut [102,103]. Another function of SSL7 is inhibition of the activity of the complement, an important defense against staphylococcal infections, by binding to the complement factor C5 [102]. Other SSLs exhibit functions that include inhibition of neutrophils and macrophages, as well as binding of glycan, Fc receptors, and P-selectin [104-108].

The exfoliative toxin A gene (eta) harbored by the chicken strain S. agnetis 908 clustered most closely with the eta of S. hyicus [40]. It was also found in S. agnetis isolates from 75\% (3/4) of mastitic milk samples [67], which was contrary to other studies in which only the etd gene (encoding exfoliative toxin D) was found among the exfoliatin genes tested (eta, etb, etd) [58]. Exfoliative toxins (ETs) are virulence factors mostly associated with $S$. aureus and S. hyicus infections [109-112]. They contribute to exfoliative epidermitis in swine and staphylococcal scalded-skin syndrome in humans. It has been shown that subcutaneous inoculation of some ETs can cause epidermis exfoliation in one-day-old chicks. However, inoculation with ETs A, B, and D originating from human S. aureus strains has shown no exfoliative activity in chicks [113-115]. It seems that ETs found in S. agnetis isolates have no effect on chickens, and to our knowledge there are no publications highlighting the role of ETs in poultry infections. The eta gene has not been found in poultry methicillin-resistant $S$ aureus (MRSA) isolates, and only rarely $(1.7 \%)$ in methicillin-sensitive S. aureus [116]. However, it should be noted that both 
S. hyicus and S. chromogenes, close relatives to S. agnetis, have been reported to produce ETs that can affect chicken epidermis $[109,114,115,117]$.

Poulsen et al. [41] theorized that the fibronectin-binding proteins (FnBPs) of S. agnetis are crucial in its ability to cause endocarditis in broiler breeders, and that FnBPs allow S. agnetis to adhere to injured endothelial cells. The role of FnBPs in the pathogenesis of S. aureus endocarditis has been proven in mammals, including humans $[97,118-120]$, but it remains to be confirmed in birds. The genome of chicken S. agnetis includes seven genes associated with FnBPs that play a role in cell adhesion $[40,41]$. The S. agnetis FnBPs appear to be distinct from those of S. hyicus, and seem to have been acquired after S. agnetis and S. hyicus diverged [40]. In the Danish strains of S. agnetis, one of the seven FnBPs can also be found in S. hyicus, while a mobile genetic element located upstream of the FnBP gene indicates a possible transfer of that gene from another staphylococcus [41]. Genes associated with FnBP production have also been found in S. agnetis isolates from mastitic milk in Finland and Canada [67,121].

\section{Antimicrobial Resistance in S. agnetis}

The antimicrobial resistance of $S$. agnetis has been studied in cattle isolates worldwide $[49,50,53,58,122]$. To our knowledge, there are no reports or data on antimicrobial resistance in poultry isolates of $S$. agnetis.

The mastitic $S$. agnetis usually show resistance to penicillin, ampicillin, cefotaxime, clindamycin, polymyxins, lysozyme (muramidase), and deferoxamine $[49,53]$, although some isolates may be sensitive to benzylpenicillin and dicloxacillin [53,122]. It is worth mentioning that $S$. agnetis has exhibited methicillin resistance associated with the mecA gene (encoding an alternative penicillin binding protein-PBP-2 $\alpha$ ) [50,58]. However, some mecA-positive strains may be susceptible to oxacillin [58]. Resistance to oxacillin (also conferring resistance to methicillin) and fusidic acid has been found in most isolates [122]. Overall, S. agnetis isolates have exhibited susceptibility to erythromycin, tetracycline, aminoglycoside antibiotics, phenicols, ciprofloxacin, trimethoprim or sulfamethoxazole, vancomycin, cephalothin, gentamicin, novobiocin, lysostaphin, and bacteriocins produced by Bacillus thuringiensis $[49,53,122]$.

Recently, the potential application of bacteriocin synthesized by $S$. agnetis has been discussed $[123,124]$. S. agnetis strain 3682 (previously S. hyicus 3682) was discovered to produce a bacteriocin, named agneticin 3682, that manifested a broad spectrum of antimicrobial action [123]. It was the first bacteriocin described in this staphylococcal species. The agneticin-producing isolate showed a marked inhibitory activity against multidrug- and methicillin-resistant $S$. aureus (MRSA). Agneticin 3682 may offer a new strategy to fight against clinical MRSA isolates [123]. Similarly, the S. agnetis strain 4S97B isolated from goat and sheep milk was reported to produce a bacteriocin able to inhibit the growth of Listeria monocytogenes. However, it was ineffective against the remaining bacterial strains tested [124]. Bacteriocins produced by poultry S. agnetis isolates have not yet been described in the available literature.

It should be noted that the available data do not reflect antimicrobial resistance in this staphylococcal species as a whole. S. agnetis isolates showed varied resistance to antimicrobial agents, which most likely mirror local production systems, flock management practices, and the use of antimicrobials [125].

\section{Host Jump of S. agnetis}

To determine phylogenetic relationships between the poultry and cattle strains of S. agnetis, phylogenetic trees were constructed [83]. Shwani et al. [83] compared the chicken S. agnetis isolates to those from cattle and identified coding sequences distinguishing isolate 908 from the cattle isolates. In total, 5 chicken (S. agnetis 908, S. agnetis 1416, and the three Danish isolates) and 31 cattle S. agnetis genomes were included. The results showed that the chicken and cattle strains were closely related with no obvious separation, but all chicken isolates clustered together. Based on these findings, Shwani et al. [83] suggested that all chicken isolates radiated from a recent single host jump, most 
probably from cattle to poultry. The dendrogram from BLAST NCBI showed the closest relationship of the U.S. chicken isolate (908) to a bovine isolate (12B) obtained from milk of a buffalo with mastitis in Argentina.

Genomic comparisons of chicken and cattle isolates were performed to identify any genes that could have promoted S. agnetis to switch from localized infections of the mammary gland in cattle to systemic infections in poultry. Of the identified genome regions or genes that showed a high similarity within the chicken isolates, but which were more distinct in the cattle isolates, none are recognizable as virulence determinants or as being capable of mediating tissue tropism. It was also determined that none of the plasmids of S. agnetis 908 showed any genes corresponding to chicken host specialization. However, it is possible that some plasmid sequences were picked after jumping to poultry [83].

The other known case of a Staphylococcus species expanding its host range to poultry was the human-to-poultry host jump of S. aureus [81]. In this example, host adaptation resulted in S. aureus acquiring mobile genetic elements from an avian-specific accessory gene pool (which included two prophages, two plasmids, and a staphylococcal pathogenicity island), losing some of its function of human disease pathogenesis by inactivation of some of the virulence factors and acquiring enhanced resistance to chicken heterophils. Murray et al. [82] noted several recombination events in 33 genes along the branch expanding to the poultry-specific cluster of $S$. aureus. A group of 47 genes was found most often within poultry isolates when compared with those of human isolates. Poultry isolates were more adapted to chicken hosts, showing enhanced growth at $42{ }^{\circ} \mathrm{C}$, and showed more pronounced chicken erythrocyte lysis. However, no such changes justifying chicken host specialization were found in S. agnetis genome. Thus, it was concluded that the cattle-to-poultry host jump of S. agnetis was probably facilitated by small alterations in a few virulence-associated factors [83].

\section{Transmission of S. agnetis}

Since $16 \mathrm{~S}$ rDNA sequences highly similar to $S$. agnetis have been found in sheep scab mites [126], it is possible that the mites or other ectoparasites act as vectors for the disease between cattle and poultry. However, attempts at finding any mites using standard methods in flocks infected with S. agnetis have failed [59].

Al-Rubaye et al. [59] demonstrated that S. agnetis could be transmitted between hens in the same pen. As it was possible to induce infection by administering $S$. agnetis in the drinking water-the probable routes of dissemination could be by direct contact, through nipple waterers, or by shedding from birds that had an early bacteremia. It was suggested that $S$. agnetis could be spread via aerosols [59]. Such a route of transmission has been proven to be possible in S. aureus infections [127].

It is possible that parent flocks can transfer S. agnetis to their offspring. In the study by Poulsen et al., $0.34 \%$ of cloacal swabs collected from newly hatched chicks originating from flocks with confirmed S. agnetis infections were positive for S. agnetis. Isolates from the chicks were of the same PFGE types as the ones found in the broiler breeder flocks they originated from. Eight flocks of broilers supplied from these broiler breeder flocks were followed for their first week of life. Birds that died during that time were examined, and in none of these birds was S. agnetis determined to be the cause of death [41].

Because of the lack of clinical trials, natural routes of S. agnetis transmission, reservoirs, and potential vectors remain unknown.

Generally, the occurrence of a staphylococcosis disease outbreak requires a pathogen in sufficient quantities, a mode of transmission, and a susceptible host. Staphylococcus breaks down host natural defenses by damage to the skin or mucous membranes, which creates an entry point for the pathogen. Immunosuppression is another way to impair host defenses. Stress; poor biosecurity or management conditions; diseases such as IBD, CIA, and MD; and other factors limiting the function of the host immune system can facilitate the outbreak of the disease [3]. Further studies are needed to confirm whether S. agnetis follows these mechanisms. 


\section{Conclusions}

Locomotor problems are a major health concern for the poultry industry worldwide. Lameness results in poor performance and substantial economic losses. There are numerous etiological factors known to cause lameness in poultry. Some factors are non-infectious, including those associated with management, housing conditions (e.g., condition of the litter), and nutrition (e.g., calcium to phosphorus ratio, vitamin D deficiency). In addition to the above, there is a wide range of infectious agents responsible for inducing lameness, including both viral and bacterial diseases (most notably infections by E. cecorum, S. aureus, avian reovirus, or Marek's disease virus). Concluding all of the research covered in this review, $S$. agnetis should be counted among all of the aforementioned agents of disease and recognized as a new emerging pathogen in poultry, not only as the causative agent of mastitis in cattle. S. agnetis has been linked to lameness in broiler chickens, as well as mortality due to septicemia and endocarditis in broiler breeders.

Author Contributions: Conceptualization, G.M.S., P.S., and B.D.; writing-original draft preparation, G.M.S. and B.D.; visualization, G.M.S. and B.D.; supervision, B.D.; writing-review and editing, G.M.S., P.S., and B.D. All authors have read and agreed to the published version of the manuscript.

Funding: This research received no special or external funding. The costs of manuscript publication were funded by the Department of Pathology and Veterinary Diagnostics, Institute of Veterinary Medicine, Warsaw University of Life Sciences-SGGW, Nowoursynowska 159c St., 02-776 Warsaw, Poland.

Acknowledgments: Staphylococcus agnetis isolate (GenBank: MT231940) shown in Figure 1 was isolated and identified by Beata Dolka, Dorota Chrobak-Chmiel, and Krzysztof Adamczyk at Department of Pathology and Veterinary Diagnostics, Institute of Veterinary Medicine, Warsaw University of Life Sciences-SGGW, Poland.

Conflicts of Interest: The authors declare no conflict of interest.

\section{References}

1. Kizerwetter-Świda, M.; Chrobak-Chmiel, D.; Rzewuska, M.; Antosiewicz, A.; Dolka, B.; Ledwoń, A.; Czujkowska, A.; Binek, M. Genetic characterization of coagulase-positive staphylococci isolated from healthy pigeons. Pol. J. Veter. Sci. 2015, 18, 627-634. [CrossRef] [PubMed]

2. Schleifer, K.-H.; Bell, J.A.; Genus, I. Staphylococcus Rosenbach 1884, 18AL (Nom. Cons. Opin. 17 Jud. Comm. 1958, 153.). In Bergey's Manual of Systematic Bacteriology: Volume 3: The Firmicutes; Bergey's Manual of Systematic Bacteriology; Whitman, W.B., Ed.; Springer New York: New York, NY, USA, 2009; pp. $392-421$. ISBN 978-0-387-95041-9.

3. Andreasen, C.B. Staphylococcosis. In Diseases of Poultry, 14th ed.; Swayne, D.E., Ed.; John Wiley \& Sons, Ltd.: Hoboken, NJ, USA, 2020; pp. 995-1003. ISBN 978-1-119-37119-9.

4. Devriese, L.A. Pathogenic staphylococci in poultry. World's Poult. Sci. J. 1980, 36, 227-236. [CrossRef]

5. Devriese, L. Staphylococci in healthy and diseased animals. J. Appl. Bacteriol. 1990, 69, 71S-80S. [CrossRef] [PubMed]

6. McNamee, P.T.; Smyth, J.A. Bacterial chondronecrosis with osteomyelitis ('femoral head necrosis') of broiler chickens: A review. Avian Pathol. 2000, 29, 253-270. [CrossRef] [PubMed]

7. McNamee, P.T.; Mccullagh, J.J.; Thorp, B.H.; Ball, H.J.; Graham, D.; McCullough, S.J.; McConaghy, D.; Smyth, J.A. Study of leg weakness in two commercial broiler flocks. Veter Rec. 1998, 143, 131-135. [CrossRef]

8. Kibenge, F.; Wilcox, G.; Pass, D. Pathogenicity of four strains of staphylococci isolated from chickens with clinical tenosynovitis. Avian Pathol. 1983, 12, 213-220. [CrossRef]

9. Jensen, M.M.; Downs, W.C.; Morrey, J.D.; Nicoll, T.R.; Lefevre, S.D.; Meyers, C.M. Staphylococcosis of Turkeys. 1. Portal of Entry and Tissue Colonization. Avian Dis. 1987, 31, 64. [CrossRef]

10. Satterfield, W.C.; O'Rourke, K.I. Staphylococcal Bumblefoot: Vaccination and Immunomodulation in the Early Treatment and Management. J. Zoo Anim. Med. 1981, 12, 95. [CrossRef]

11. Olsen, R.H.; Christensen, H.; Kabell, S.; Bisgaard, M. Characterization of prevalent bacterial pathogens associated with pododermatitis in table egg layers. Avian Pathol. 2018, 47, 281-285. [CrossRef]

12. Nairn, M.E. Bacterial Osteomyelitis and Synovitis of the Turkey. Avian Dis. 1973, 17, 504. [CrossRef]

13. Huff, G.R.; Huff, W.E.; Rath, N.C.; Balog, J.M. Turkey Osteomyelitis Complex. Poult. Sci. 2000, 79, $1050-1056$. [CrossRef] [PubMed] 
14. Marek, A.; Steppień-Pyśniak, D.; Pyzik, E.; Adaszek, Ł.; Wilczyński, J.; Winiarczyk, S. Occurrence and characterization of Staphylococcus bacteria isolated from poultry in Western Poland. Berliner Munchener Tierarztliche Wochenschrift 2016, 129, 147-152.

15. Peton, V.; Le Loir, Y. Staphylococcus aureus in veterinary medicine. Infect. Genet. Evol. 2014, 21, $602-615$. [CrossRef] [PubMed]

16. DG SANTE. Report from the Commission to the European Parliament and the Council on the Impact of Genetic Selection on the Welfare of Chickens Kept for Meat Production COM/2016/0182 Final. Available online: https://ec.europa.eu/transparency/regdoc/rep/1/2016/EN/1-2016-182-EN-F1-1.PDF (accessed on 13 June 2020).

17. Gocsik, É.; Silvera, A.M.; Hansson, H.; Saatkamp, H.W.; Blokhuis, H. Exploring the economic potential of reducing broiler lameness. Br. Poult. Sci. 2017, 58, 337-347. [CrossRef] [PubMed]

18. Granquist, E.G.; Vasdal, G.; De Jong, I.C.; Moe, R.O. Lameness and its relationship with health and production measures in broiler chickens. Animal 2019, 13, 2365-2372. [CrossRef]

19. Butterworth, A. Infectious components of broiler lameness: A review. World's Poult. Sci. J. 1999, 55, 327-352. [CrossRef]

20. Jones, R. Avian reovirus infections. Rev. Sci. Tech. l'OIE 2000, 19, 614-625. [CrossRef]

21. De Gussem, J.; Swam, H.; Lievens, K.; De Herdt, P. Reovirus tenosynovitis in a flock of layer breeders. Avian Pathol. 2010, 39, 169-170. [CrossRef]

22. Dolka, B.; Chrobak-Chmiel, D.; Makrai, L.; Szeleszczuk, P. Phenotypic and genotypic characterization of Enterococcus cecorum strains associated with infections in poultry. BMC Veter. Res. 2016, 12, 129. [CrossRef]

23. Wideman, R.F.J. Bacterial chondronecrosis with osteomyelitis and lameness in broilers: A review. Poult. Sci. 2016, 95, 325-344. [CrossRef]

24. Ramp, W.K.; Baker, R.L.; Trinkle, L.S. Interrelationships of vitamin D, bone metabolism and blood calcium concentration in the chick. Bone Miner. 1989, 5, 117-128. [CrossRef]

25. $\mathrm{Xu}, \mathrm{T}$;; Leach, R.M.; Hollis, B.; Soares, J.H. Evidence of increased cholecalciferol requirement in chicks with tibial dyschondroplasia. Poult. Sci. 1997, 76, 47-53. [CrossRef] [PubMed]

26. Webster, A.B. Welfare implications of avian osteoporosis. Poult. Sci. 2004, 83, 184-192. [CrossRef] [PubMed]

27. Sun, Z.W.; Yan, L.; Zhao, J.P.; Lin, H.; Guo, Y.M. Increasing dietary vitamin D3 improves the walking ability and welfare status of broiler chickens reared at high stocking densities. Poult. Sci. 2013, 92, 3071-3079. [CrossRef]

28. Akter, M.; Graham, H.; Iji, P.A. Response of broiler chickens to different levels of calcium, non-phytate phosphorus and phytase. Br. Poult. Sci. 2016, 57, 799-809. [CrossRef]

29. Dozier, W.A.; Thaxton, J.P.; Purswell, J.L.; Olanrewaju, H.A.; Branton, S.L.; Roush, W.B. Stocking Density Effects on Male Broilers Grown to 1.8 Kilograms of Body Weight. Poult. Sci. 2006, 85, 344-351. [CrossRef]

30. Mayne, R.; Else, R.; Hocking, P.M. High litter moisture alone is sufficient to cause footpad dermatitis in growing turkeys. Br. Poult. Sci. 2007, 48, 538-545. [CrossRef]

31. Knowles, T.; Kestin, S.C.; Haslam, S.M.; Brown, S.N.; Green, L.E.; Butterworth, A.; Pope, S.J.; Pfeiffer, D.; Nicol, C.J. Leg Disorders in Broiler Chickens: Prevalence, Risk Factors and Prevention. PLoS ONE 2008, 3, e1545. [CrossRef]

32. Meluzzi, A.; Fabbri, C.; Folegatti, E.; Sirri, F. Effect of less intensive rearing conditions on litter characteristics, growth performance, carcase injuries and meat quality of broilers. Br. Poult. Sci. 2008, 49, 509-515. [CrossRef]

33. Kaukonen, E.; Norring, M.; Valros, A. Effect of litter quality on foot pad dermatitis, hock burns and breast blisters in broiler breeders during the production period. Avian Pathol. 2016, 45, 667-673. [CrossRef]

34. Kaukonen, E.; Norring, M.; Valros, A. Evaluating the effects of bedding materials and elevated platforms on contact dermatitis and plumage cleanliness of commercial broilers and on litter condition in broiler houses. Br. Poult. Sci. 2017, 58, 480-489. [CrossRef]

35. Kestin, S.; Knowles, T.; Tinch, A.; Gregory, N. Prevalence of leg weakness in broiler chickens and its relationship with genotype. Veter. Rec. 1992, 131, 190-194. [CrossRef] [PubMed]

36. González-Cerón, F.; Rekaya, R.; Anthony, N.B.; Aggrey, S.E. Genetic analysis of leg problems and growth in a random mating broiler population. Poult. Sci. 2015, 94, 162-168. [CrossRef] [PubMed]

37. Julian, R.J. Rapid growth problems: Ascites and skeletal deformities in broilers. Poult. Sci. 1998, 77, 1773-1780. [CrossRef]

38. Leterrier, C.; Nys, Y. Composition, cortical structure and mechanical properties of chicken tibiotarsi: Effect of growth rate. Br. Poult. Sci. 1992, 33, 925-939. [CrossRef] [PubMed] 
39. Shim, M.Y.; Karnuah, A.B.; Mitchell, A.D.; Anthony, N.B.; Pesti, G.M.; Aggrey, S.E. The effects of growth rate on leg morphology and tibia breaking strength, mineral density, mineral content, and bone ash in broilers. Poult. Sci. 2012, 91, 1790-1795. [CrossRef] [PubMed]

40. Al-Rubaye, A.A.K.; Couger, M.B.; Ojha, S.; Pummill, J.F.; Koon, J.A.; Wideman, R.F.; Rhoads, D.D. Genome Analysis of Staphylococcus agnetis, an Agent of Lameness in Broiler Chickens. PLoS ONE 2015, 10, e0143336. [CrossRef] [PubMed]

41. Poulsen, L.L.; Thøfner, I.C.N.; Bisgaard, M.; Olsen, R.H.; Christensen, J.P.; Christensen, H. Staphylococcus agnetis, a potential pathogen in broiler breeders. Veter. Microbiol. 2017, 212, 1-6. [CrossRef]

42. Awan, M.; Matsumoto, M. Heterogeneity of staphylococci and other bacteria isolated from six-week-old broiler chickens. Poult. Sci. 1998, 77, 944-949. [CrossRef] [PubMed]

43. Tsai, S.-S.; Chen, L.-J.; Shih, C.-Y.; Chang, T.-C.; Chiou, M.-T.; Chuang, K.P. Joint Lesions in Taiwan native colored broiler chicken with natural and experimental Staphylococcus aureus or S. cohnii Infection. Taiwan Veter. J. 2015, 41, 237-244. [CrossRef]

44. Scanlan, C.M.; Hargis, B.M. A Bacteriologic Study of Scabby-Hip Lesions from Broiler Chickens in Texas. J. Veter. Diagn. Investig. 1989, 1, 170-173. [CrossRef] [PubMed]

45. Cheville, N.F.; Tappe, J.; Ackermann, M.; Jensen, A. Acute Fibrinopurulent Blepharitis and Conjunctivitis Associated with Staphylococcus hyicus, Escherichia coli, and Streptococcus sp. in Chickens and Turkeys. Veter. Pathol. 1988, 25, 369-375. [CrossRef] [PubMed]

46. Devriese, L.A.; Uyttebroek, E.; Dom, P.; De Herdt, P.; Ducatelle, R.; Haesebrouck, F. Staphylococcus hyicus associated with pox in chickens and in turkeys. Avian Pathol. 1992, 21, 529-533. [CrossRef] [PubMed]

47. Tate, C.R.; Mitchell, W.C.; Miller, R.G. Staphylococcus hyicus Associated with Turkey Stifle Joint Osteomyelitis. Avian Dis. 1993, 37, 905. [CrossRef]

48. Chénier, S.; Lallier, L. Acantholytic Folliculitis and Epidermitis Associated with Staphylococcus hyicus in a Line of White Leghorn Laying Chickens. Veter. Pathol. 2011, 49, 284-287. [CrossRef]

49. Taponen, S.; Supré, K.; Piessens, V.; Van Coillie, E.; De Vliegher, S.; Koort, J. Staphylococcus agnetis sp. nov., a coagulase-variable species from bovine subclinical and mild clinical mastitis. Int. J. Syst. Evol. Microbiol. 2012, 62, 61-65. [CrossRef]

50. Cicconi-Hogan, K.; Belomestnykh, N.; Gamroth, M.; Ruegg, P.; Tikofsky, L.; Schukken, Y. Short communication: Prevalence of methicillin resistance in coagulase-negative staphylococci and Staphylococcus aureus isolated from bulk milk on organic and conventional dairy farms in the United States. J. Dairy Sci. 2014, 97, 2959-2964. [CrossRef]

51. Calcutt, M.J.; Foecking, M.F.; Fry, P.R.; Hsieh, H.-Y.; Perry, J.; Stewart, G.C.; Scholl, D.T.; Messier, S.; Middleton, J.R. Draft Genome Sequence of Bovine Mastitis Isolate Staphylococcus agnetis CBMRN 20813338. Genome Announc. 2014, 2, e00883-14. [CrossRef]

52. Lange, C.C.; Brito, M.A.; Reis, D.R.; Machado, M.A.; Guimarães, A.S.; Azevedo, A.L.; Salles, É.B.; Alvim, M.C.; Silva, F.S.; Meurer, I.R. Species-level identification of staphylococci isolated from bovine mastitis in Brazil using partial $16 \mathrm{~S}$ rRNA sequencing. Veter. Microbiol. 2015, 176, 382-388. [CrossRef]

53. León-Galván, M.F.; Barboza-Corona, J.E.; Lechuga-Arana, A.A.; Valencia-Posadas, M.; Aguayo, D.D.; Cedillo-Peláez, C.; Martínez-Ortega, E.A.; Gutiérrez-Chávez, A.J. Molecular Detection and Sensitivity to Antibiotics and Bacteriocins of Pathogens Isolated from Bovine Mastitis in Family Dairy Herds of Central Mexico. BioMed Res. Int. 2015, 2015, 615153. [CrossRef]

54. Adkins, P.; Middleton, J.R.; Calcutt, M.J.; Stewart, G.C.; Fox, L.K. Species Identification and Strain Typing of Staphylococcus agnetis and Staphylococcus hyicus Isolates from Bovine Milk by Use of a Novel Multiplex PCR Assay and Pulsed-Field Gel Electrophoresis. J. Clin. Microbiol. 2017, 55, 1778-1788. [CrossRef] [PubMed]

55. Adkins, P.; Dufour, S.; Spain, J.; Calcutt, M.; Reilly, T.; Stewart, G.; Middleton, J. Molecular characterization of non-aureus Staphylococcus spp. from heifer intramammary infections and body sites. J. Dairy Sci. 2018, 101, 5388-5403. [CrossRef] [PubMed]

56. Adkins, P.; Dufour, S.; Spain, J.; Calcutt, M.; Reilly, T.; Stewart, G.; Middleton, J. Cross-sectional study to identify staphylococcal species isolated from teat and inguinal skin of different-aged dairy heifers. J. Dairy Sci. 2018, 101, 3213-3225. [CrossRef] [PubMed]

57. Condas, L.A.Z.; De Buck, J.; Nobrega, D.; Carson, D.A.; Roy, J.-P.; Keefe, G.P.; Devries, T.J.; Middleton, J.R.; Dufour, S.; Barkema, H. Distribution of non-aureus staphylococci species in udder quarters with low and high somatic cell count, and clinical mastitis. J. Dairy Sci. 2017, 100, 5613-5627. [CrossRef] [PubMed] 
58. Mahato, S.; Mistry, H.U.; Chakraborty, S.; Sharma, P.; Saravanan, R.; Bhandari, V. Identification of Variable Traits among the Methicillin Resistant and Sensitive Coagulase Negative Staphylococci in Milk Samples from Mastitic Cows in India. Front. Microbiol. 2017, 8, 8. [CrossRef]

59. Al-Rubaye, A.A.K.; Ekesi, N.S.; Zaki, S.; Emami, N.K.; Wideman, R.F.; Rhoads, D.D. Chondronecrosis with osteomyelitis in broilers: Further defining a bacterial challenge model using the wire flooring model. Poult. Sci. 2017, 96, 332-340. [CrossRef]

60. Freney, J.; Kloos, W.E.; Hájek, V.; Webster, J.A.; Bes, M.; Brun, Y.; Vernozy-Rozand, C. Recommended minimal standards for description of new staphylococcal species. Int. J. Syst. Evol. Microbiol. 1999, 49, 489-502. [CrossRef]

61. Wanecka, A.; Król, J.; Twardoń, J.; Mrowiec, J.; Korzeniowska-Kowal, A.; Wzorek, A. Efficacy of MALDI-TOF mass spectrometry as well as genotypic and phenotypic methods in identification of staphylococci other than Staphylococcus aureus isolated from intramammary infections in dairy cows in Poland. J. Veter. Diagn. Investig. 2019, 31, 523-530. [CrossRef]

62. Pizauro, L.J.L.; De Almeida, C.C.; Soltes, G.A.; Slavic, D.; Rossi-Junior, O.D.; De Ávila, F.A.; Zafalon, L.F.; MacInnes, J.I. Species level identification of coagulase negative Staphylococcus spp. from buffalo using matrix-assisted laser desorption ionization-time of flight mass spectrometry and $c y d B$ real-time quantitative PCR. Veter. Microbiol. 2017, 204, 8-14. [CrossRef]

63. Piessens, V.; Van Coillie, E.; Verbist, B.; Supré, K.; Braem, G.; Van Nuffel, A.; De Vuyst, L.; Heyndrickx, M.; De Vliegher, S. Distribution of coagulase-negative Staphylococcus species from milk and environment of dairy cows differs between herds. J. Dairy Sci. 2011, 94, 2933-2944. [CrossRef]

64. Devriese, L.A.; Hájek, V.; Oeding, P.; Meyer, S.A.; Schleifer, K.H.; Davis, D.H.; Doudoroff, M.; Stanier, R.Y.; Mandel, M. Staphylococcus hyicus (Sompolinsky 1953) comb. nov. and Staphylococcus hyicus subsp. chromogenes subsp. nov. Int. J. Syst. Bacteriol. 1978, 28, 482-490. [CrossRef]

65. Dos Santos, D.C.; Lange, C.C.; Avellar-Costa, P.; Dos Santos, K.R.N.; Brito, M.A.V.P.; Giambiagi-Demarval, M. Staphylococcus chromogenes, a Coagulase-Negative Staphylococcus Species That Can Clot Plasma. J. Clin. Microbiol. 2016, 54, 1372-1375. [CrossRef] [PubMed]

66. Hájek, V.; Devriese, L.; Mordarski, M.; Goodfellow, M.; Pulverer, G.; Varaldo, P. Elevation of Staphylococcus hyicus subsp. chromogenes (Devriese et al., 1978) to species status: Staphylococcus chromogenes (Devriese et al., 1978) comb. nov. Syst. Appl. Microbiol. 1986, 8, 169-173. [CrossRef]

67. Åvall-Jääskeläinen, S.T.; Taponen, S.; Kant, R.; Paulin, L.; Blom, J.; Palva, A.; Koort, J. Comparative genome analysis of 24 bovine-associated Staphylococcus isolates with special focus on the putative virulence genes. PeerJ 2018, 6, e4560. [CrossRef]

68. Nairn, M.E.; Watson, A.R.A. Leg weakness of poultry-A clinical and pathological characterisation. Aust. Veter. J. 1972, 48, 645-656. [CrossRef]

69. Sanotra, G.S.; Lund, J.D.; Ersbøll, A.K.; Petersen, J.S.; Vestergaard, K.S. Monitoring leg problems in broilers: A survey of commercial broiler production in Denmark. World's Poult. Sci. J. 2001, 57, 55-69. [CrossRef]

70. Wijesurendra, D.S.; Chamings, A.; Bushell, R.N.; Rourke, D.O.; Stevenson, M.; Marenda, M.; Noormohammadi, A.H.; Stent, A. Pathological and microbiological investigations into cases of bacterial chondronecrosis and osteomyelitis in broiler poultry. Avian Pathol. 2017, 46, 1-12. [CrossRef]

71. Morris, M.P. National survey of leg problems. Broiler Ind. 1993, 56, 20-24.

72. Nicol, C.J. Welfare issues in commercial broiler production. In Poultry Development Review; FAO: Rome, Italy, 2013; pp. 117-118. ISBN 978-92-5-108067-2.

73. Wideman, R.F.J.; Hamal, K.R.; Stark, J.M.; Blankenship, J.; Lester, H.; Mitchell, K.N.; Lorenzoni, G.; Pevzner, I. A wire-flooring model for inducing lameness in broilers: Evaluation of probiotics as a prophylactic treatment. Poult. Sci. 2012, 91, 870-883. [CrossRef]

74. Vesterlund, S.; Karp, M.; Salminen, S.; Ouwehand, A.C. Staphylococcus aureus adheres to human intestinal mucus but can be displaced by certain lactic acid bacteria. Microbiology 2006, 152, 1819-1826. [CrossRef]

75. Hess, D.J.; Henry-Stanley, M.J.; Erickson, E.A.; Wells, C.L. Intracellular survival of Staphylococcus aureus within cultured enterocytes. J. Surg. Res. 2003, 114, 42-49. [CrossRef]

76. Sendi, P.; Proctor, R.A. Staphylococcus aureus as an intracellular pathogen: The role of small colony variants. Trends Microbiol. 2009, 17, 54-58. [CrossRef] [PubMed] 
77. Koenen, M.E.; Kramer, J.; Van Der Hulst, R.; Heres, L.; Jeurissen, S.H.M.; Boersma, W.J.A. Immunomodulation by probiotic lactobacilli in layer- and meat-type chickens. Br. Poult. Sci. 2004, 45, 355-366. [CrossRef] [PubMed]

78. Saint-Cyr, M.J.; Guyard-Nicodème, M.; Messaoudi, S.; Chemaly, M.; Cappelier, J.-M.; Dousset, X.; Haddad, N. Recent Advances in Screening of Anti-Campylobacter Activity in Probiotics for Use in Poultry. Front. Microbiol. 2016, 7. [CrossRef] [PubMed]

79. Alagawany, M.; El-Hack, M.E.A.; Farag, M.R.; Sachan, S.; Karthik, K.; Dhama, K. The use of probiotics as eco-friendly alternatives for antibiotics in poultry nutrition. Environ. Sci. Pollut. Res. 2018, 25, 10611-10618. [CrossRef]

80. Wideman, R.F.J.; Al-Rubaye, A.; Kwon, Y.M.; Blankenship, J.; Lester, H.; Mitchell, K.N.; Pevzner, I.Y.; Lohrmann, T.; Schleifer, J. Prophylactic administration of a combined prebiotic and probiotic, or therapeutic administration of enrofloxacin, to reduce the incidence of bacterial chondronecrosis with osteomyelitis in broilers. Poult. Sci. 2015, 94, 25-36. [CrossRef]

81. Lowder, B.V.; Guinane, C.M.; Ben Zakour, N.L.; Weinert, L.A.; Morris, A.C.; Cartwright, R.A.; Simpson, A.J.; Rambaut, A.; Nübel, U.; Fitzgerald, J.R. Recent human-to-poultry host jump, adaptation, and pandemic spread of Staphylococcus aureus. Proc. Natl. Acad. Sci. USA 2009, 106, 19545-19550. [CrossRef]

82. Murray, S.; Pascoe, B.; Méric, G.; Mageiros, L.; Yahara, K.; Hitchings, M.D.; Friedmann, Y.; Wilkinson, T.S.; Gormley, F.J.; Mack, D.; et al. Recombination-Mediated Host Adaptation by Avian Staphylococcus aureus. Genome Boil. Evol. 2017, 9, 830-842. [CrossRef]

83. Shwani, A.; Adkins, P.R.F.; Ekesi, N.S.; Alrubaye, A.; Calcutt, M.J.; Middleton, J.R.; Rhoads, D.D. Whole-Genome Comparisons of Staphylococcus agnetis Isolates from Cattle and Chickens. Appl. Environ. Microbiol. 2020, 86, 86. [CrossRef]

84. Borst, L.B. Streptococcus and Enterococcus. In Diseases of Poultry, 14th ed.; Swayne, D.E., Ed.; John Wiley \& Sons, Ltd.: Hoboken, NJ, USA, 2020; pp. 1003-1010. ISBN 978-1-119-37119-9.

85. A Petti, C.; Jr Fowler, V.G. Staphylococcus aureus bacteremia and endocarditis. Cardiol. Clin. 2003, 21, $219-233$. [CrossRef]

86. Asgeirsson, H.; Thalme, A.; Weiland, O. Staphylococcus aureus bacteraemia and endocarditis-Epidemiology and outcome: A review. Infect. Dis. 2017, 50, 175-192. [CrossRef] [PubMed]

87. Bisgaard, M.; Bojesen, A.M.; Christensen, J.P.; Christensen, H. Observations on the incidence and aetiology of valvular endocarditis in broiler breeders and detection of a newly described taxon of Pasteurellaceae, Avibacterium endocarditidis. Avian Pathol. 2010, 39, 177-181. [CrossRef] [PubMed]

88. Stępień-Pyśniak, D.; Wilczyński, J.; Marek, A.; Śmiech, A.; Kosikowska, U.; Hauschild, T. Staphylococcus simulans associated with endocarditis in broiler chickens. Avian Pathol. 2016, 46, 1-26. [CrossRef] [PubMed]

89. Chadfield, M.S.; Bojesen, A.M.; Christensen, J.P.; Juul-Hansen, J.; Nielsen, S.S.; Bisgaard, M. Reproduction of sepsis and endocarditis by experimental infection of chickens with Streptococcus gallinaceus and Enterococcus hirae. Avian Pathol. 2005, 34, 238-247. [CrossRef] [PubMed]

90. Sekizaki, T.; Nishiya, H.; Nakajima, S.; Nishizono, M.; Kawano, M.; Okura, M.; Takamatsu, D.; Nishino, H.; Ishiji, T.; Osawa, R. Endocarditis in Chickens Caused by Subclinical Infection of Streptococcus gallolyticus subsp. gallolyticus. Avian Dis. 2008, 52, 183-186. [CrossRef] [PubMed]

91. Wang, Q.; Chang, B.J.; Riley, T.V. Erysipelothrix rhusiopathiae. Veter. Microbiol. 2010, 140, 405-417. [CrossRef]

92. Crispo, M.; Stoute, S.; Savaris, T.; Bickford, A.; Santoro, T.; Sentíes-Cué, C.G. Vegetative Valvular Endocarditis and Hepatitis Associated with Helcococcus ovis in a 7-year-old White Leghorn Rooster. Avian Dis. 2017, 61, 526-530. [CrossRef]

93. Dolka, B.; Cisek, A.A.; Szeleszczuk, P. The application of the loop-mediated isothermal amplification (LAMP) method for diagnosing Enterococcus hirae-associated endocarditis outbreaks in chickens. BMC Microbiol. 2019, 19, 48. [CrossRef]

94. Gross, W.B.; Domermuth, C.H. Bacterial endocarditis of poultry. Am. J. Veter. Res. 1962, 23, 320-329.

95. Chadfield, M.S.; Christensen, J.P.; Christensen, H.; Bisgaard, M. Characterization of streptococci and enterococci associated with septicaemia in broiler parents with a high prevalence of endocarditis. Avian Pathol. 2004, 33, 610-617. [CrossRef]

96. Velkers, F.C.; Van De Graaf-Bloois, L.; Wagenaar, J.; Westendorp, S.; Van Bergen, M.; Dwars, R.; Landman, W.J.M. Enterococcus hirae-associated endocarditis outbreaks in broiler flocks: Clinical and pathological characteristics and molecular epidemiology. Veter. Q. 2011, 31, 3-17. [CrossRef] [PubMed] 
97. Tong, S.Y.C.; Davis, J.S.; Eichenberger, E.; Holland, T.L.; Fowler, V.G., Jr. Staphylococcus aureus Infections: Epidemiology, Pathophysiology, Clinical Manifestations, and Management. Clin. Microbiol. Rev. 2015, 28, 603-661. [CrossRef] [PubMed]

98. Fraser, J.; Proft, T. The bacterial superantigen and superantigen-like proteins. Immunol. Rev. 2008, 225, 226-243. [CrossRef] [PubMed]

99. Katayama, Y.; Baba, T.; Sekine, M.; Fukuda, M.; Hiramatsu, K. Beta-Hemolysin Promotes Skin Colonization by Staphylococcus aureus. J. Bacteriol. 2013, 195, 1194-1203. [CrossRef] [PubMed]

100. Otto, M. Staphylococcus aureus toxins. Curr. Opin. Microbiol. 2013, 17, 32-37. [CrossRef]

101. Oliveira, D.; Borges, A.; Simões, M. Staphylococcus aureus Toxins and Their Molecular Activity in Infectious Diseases. Toxins 2018, 10, 252. [CrossRef]

102. Langley, R.; Wines, B.; Willoughby, N.; Basu, I.; Proft, T.; Fraser, J.D. The Staphylococcal Superantigen-Like Protein 7 Binds IgA and Complement C5 and Inhibits IgA-Fc $\alpha$ RI Binding and Serum Killing of Bacteria. J. Immunol. 2005, 174, 2926-2933. [CrossRef]

103. Broom, L.J. Gut barrier function: Effects of (antibiotic) growth promoters on key barrier components and associations with growth performance. Poult. Sci. 2018, 97, 1572-1578. [CrossRef]

104. Baker, H.M.; Basu, I.; Chung, M.C.; Caradoc-Davies, T.; Fraser, J.D.; Baker, E.N. Crystal Structures of the Staphylococcal Toxin SSL5 in Complex with Sialyl Lewis X Reveal a Conserved Binding Site that Shares Common Features with Viral and Bacterial Sialic Acid Binding Proteins. J. Mol. Boil. 2007, 374, 1298-1308. [CrossRef]

105. Bestebroer, J.; Poppelier, M.J.J.G.; Ulfman, L.H.; Lenting, P.J.; Denis, C.V.; Van Kessel, K.P.; Van Strijp, J.A.; De Haas, C.J.C. Staphylococcal superantigen-like 5 binds PSGL-1 and inhibits P-selectin-mediated neutrophil rolling. Blood 2006, 109, 2936-2943. [CrossRef]

106. Chung, M.C.; Wines, B.D.; Baker, H.; Langley, R.; Baker, E.N.; Fraser, J.D. The crystal structure of staphylococcal superantigen-like protein 11 in complex with sialyl Lewis $\mathrm{X}$ reveals the mechanism for cell binding and immune inhibition. Mol. Microbiol. 2007, 66, 1342-1355. [CrossRef] [PubMed]

107. Hermans, S.J.; Baker, H.M.; Sequeira, R.P.; Langley, R.; Baker, E.N.; Fraser, J.D. Structural and Functional Properties of Staphylococcal Superantigen-Like Protein 4. Infect. Immun. 2012, 80, 4004-4013. [CrossRef] [PubMed]

108. Koymans, K.J.; Bisschop, A.; Vughs, M.M.; Van Kessel, K.P.; De Haas, C.J.C.; Van Strijp, J.A. Staphylococcal Superantigen-Like Protein 1 and 5 (SSL1 \& SSL5) Limit Neutrophil Chemotaxis and Migration through MMP-Inhibition. Int. J. Mol. Sci. 2016, 17, 1072. [CrossRef]

109. Tanabe, T.; Sato, H.; Sato, H.; Watanabe, K.; Hirano, M.; Hirose, K.; Kurokawa, S.; Nakano, K.; Saito, H.; Maehara, N. Correlation between occurrence of exudative epidermitis and exfoliative toxin-producing ability of Staphylococcus hyicus. Veter. Microbiol. 1996, 48, 9-17. [CrossRef]

110. Fudaba, Y.; Nishifuji, K.; Andresen, L.O.; Yamaguchi, T.; Komatsuzawa, H.; Amagai, M.; Sugai, M. Staphylococcus hyicus exfoliative toxins selectively digest porcine desmoglein 1. Microb. Pathog. 2005, 39, 171-176. [CrossRef] [PubMed]

111. Ladhani, S.N.; Joannou, C.L.; Lochrie, D.P.; Evans, R.W.; Poston, S.M. Clinical, Microbial, and Biochemical Aspects of the Exfoliative Toxins Causing Staphylococcal Scalded-Skin Syndrome. Clin. Microbiol. Rev. 1999, 12, 224-242. [CrossRef]

112. Bukowski, M.; Wladyka, B.; Dubin, G. Exfoliative Toxins of Staphylococcus aureus. Toxins 2010, 2, 1148-1165. [CrossRef]

113. Yamaguchi, T.; Nishifuji, K.; Sasaki, M.; Fudaba, Y.; Aepfelbacher, M.; Takata, T.; Ohara, M.; Komatsuzawa, H.; Amagai, M.; Sugai, M. Identification of the Staphylococcus aureus etd Pathogenicity Island Which Encodes a Novel Exfoliative Toxin, ETD, and EDIN-B. Infect. Immun. 2002, 70, 5835-5845. [CrossRef]

114. Sato, H.; Matsumori, Y.; Tanabe, T.; Shimizu, A.; Kawano, J. A new type of staphylococcal exfoliative toxin from a Staphylococcus aureus strain isolated from a horse with phlegmon. Infect. Immun. 1994, 62, 3780-3785. [CrossRef]

115. Sato, H.; Watanabe, T.; Murata, Y.; Ohtake, A.; Nakamura, M.; Aizawa, C.; Saito, H.; Maehara, N. New Exfoliative Toxin Produced by a Plasmid-Carrying Strain of Staphylococcus hyicus. Infect. Immun. 1999, 67, 4014-4018. [CrossRef] 
116. Marek, A.; Pyzik, E.; Stepien-Pysniak, D.; Urban-Chmiel, R.; Jarosz, Ł. Association Between the Methicillin Resistance of Staphylococcus aureus Isolated from Slaughter Poultry, Their Toxin Gene Profiles and Prophage Patterns. Curr. Microbiol. 2018, 75, 1256-1266. [CrossRef] [PubMed]

117. Sato, H.; Hirose, K.; Terauchi, R.; Abe, S.; Moromizato, I.; Kurokawa, S.; Maehara, N. Purification and Characterization of a novel Staphylococcus chromogenes Exfoliative Toxin. J. Veter Med. Ser. B 2004, 51, 116-122. [CrossRef] [PubMed]

118. Que, Y.-A.; Haefliger, J.A.; Piroth, L.; François, P.; Widmer, E.; Entenza, J.M.; Sinha, B.; Herrmann, M.; Francioli, P.; Vaudaux, P.; et al. Fibrinogen and fibronectin binding cooperate for valve infection and invasion in Staphylococcus aureus experimental endocarditis. J. Exp. Med. 2005, 201, 1627-1635. [CrossRef] [PubMed]

119. Piroth, L.; Que, Y.-A.; Widmer, E.; Panchaud, A.; Piu, S.; Entenza, J.M.; Moreillon, P. The Fibrinogen- and Fibronectin-Binding Domains of Staphylococcus aureus Fibronectin-Binding Protein a Synergistically Promote Endothelial Invasion and Experimental Endocarditis. Infect. Immun. 2008, 76, 3824-3831. [CrossRef] [PubMed]

120. Foster, T.J. The remarkably multifunctional fibronectin binding proteins of Staphylococcus aureus. Eur. J. Clin. Microbiol. Infect. Dis. 2016, 35, 1923-1931. [CrossRef]

121. Naushad, S.; Naqvi, S.A.; Nobrega, D.; Luby, C.; Kastelic, J.; Barkema, H.; De Buck, J. Comprehensive Virulence Gene Profiling of Bovine Non-aureus Staphylococci Based on Whole-Genome Sequencing Data. mSystems 2019, 4. [CrossRef]

122. Taponen, S.; Nykäsenoja, S.; Pohjanvirta, T.; Pitkälä, A.H.; Pyörälä, S. Species distribution and in vitro antimicrobial susceptibility of coagulase-negative staphylococci isolated from bovine mastitic milk. Acta Veter. Scand. 2016, 58, 12. [CrossRef]

123. Fagundes, P.C.; Francisco, M.S.; Santos, I.N.S.; Marques-Bastos, S.L.S.; Paz, J.A.S.; Albano, R.M.; Bastos, M.D.C.D.F. Draft genome sequence of Staphylococcus agnetis 3682, the producing strain of the broad-spectrum lantibiotic agneticin 3682. J. Glob. Antimicrob. Resist. 2019, 19, 50-52. [CrossRef]

124. Rahmdel, S.; Shekarforoush, S.S.; Hosseinzadeh, S.; Torriani, S.; Gatto, V. Antimicrobial spectrum activity of bacteriocinogenic Staphylococcus strains isolated from goat and sheep milk. J. Dairy Sci. 2019, 102, 2928-2940. [CrossRef]

125. Van Boeckel, T.P.; Brower, C.; Gilbert, M.; Grenfell, B.T.; Levin, S.A.; Robinson, T.P.; Teillant, A.; Laxminarayan, R. Global trends in antimicrobial use in food animals. Proc. Natl. Acad. Sci. USA 2015, 112, 5649-5654. [CrossRef]

126. Hogg, J.C.; Lehane, M.J. Identification of Bacterial Species Associated with the Sheep Scab Mite (Psoroptes ovis) by Using Amplified Genes Coding for $16 S$ rRNA. Appl. Environ. Microbiol. 1999, 65, 4227-4229. [CrossRef] [PubMed]

127. McNamee, P.T.; Mccullagh, J.J.; Rodgers, J.D.; Thorp, B.H.; Ball, H.J.; Connor, T.J.; McConaghy, D.; Smyth, J.A. Development of an experimental model of bacterial chondronecrosis with osteomyelitis in broilers following exposure to Staphylococcus aureus by aerosol, and inoculation with chicken anaemia and infectious bursal disease viruses. Avian Pathol. 1999, 28, 26-35. [CrossRef] [PubMed]

(C) 2020 by the authors. Licensee MDPI, Basel, Switzerland. This article is an open access article distributed under the terms and conditions of the Creative Commons Attribution (CC BY) license (http://creativecommons.org/licenses/by/4.0/). 